\title{
In and About the Maximus Poems
}

\section{The Maximus Poems 1-10}

1953: a good year. The Maximus Poems 1-10 appeared in the summer, in Stuttgart, thanks to Jonathan Williams, a student of Olson's at Black Mountain; In Cold Hell, In Thicket preceded it, the fullest early collection of Olson's poems, the entire issue of Origin 8, Cid Corman's little magazine, edited and printed in this instance by Robert Creeley at his Divers Press in Mallorca; and Mayan Letters, also printed by Creeley, to whom the letters are addressed, followed, actually appearing at the turn of the year. Seven of the ten Maximus poems were written in the spring of this year, at Black Mountain (only in the winter of 1957-58, when Black Mountain was behind him, did Olson take up residence in Gloucester, where almost all of the third installment of Maximus was written), and the publication of the poems, so quickly and so handsomely, must have been as gratifying to him as the receipt of Origin 8, acknowledged in "Letter 9" of Maximus. Testimony, certainly, of flowering, of the incredible growth and fruition of this decade, the most remarkable, the high point of his career.

Chronological order is implicit in the practice of projective verse. As William Carlos Williams said of The Maximus Poems, "This is a story of the events of a man's experience and the particular events of a man's experience. ..."Williams, also indebted to Whitehead, perhaps appreciated the accuracy of "events"; a poem is an event, the actualization of its occasion. Set out chronologically, the poems tell that story, in this simple sequential way are narrative. We search for other modes of coherence, for themes, perhaps for historical narrative, but most essential to understanding The Maximus Poems is Olson's adherence to the method of field composition in which stance toward reality is all-important and the poems that issue from the poet's participation in the field of his life enact the movement of his attention. Williams' comment on the first two volumes-"categorically this book [Maximus 11-22] is much better than the first [Maximus 1-10] by which I was often defeated"-also reminds us that the poems were, and remain, work-in-progress, appeared in installments, chronologically, and that we, too, might consider them in this way.

Williams doesn't tell us why he was defeated by the first and not also by the second installment of poems. Perhaps familiarity is accepting, for his central criticism of both volumes is the same-that too often too much that is essential is left out and too much that is inessential is included. This is not, 
I think, the case in any acceptable sense of "essential," and it is not now the case because there is annotation enough to make the poems readily accessible. The most "difficult" poem, "Tyrian Businesses" ("Letter 8"), is a part of the occasion that included "A Syllabary for a Dancer," an essay published in MAPS, in 1971, that the poem itself takes up, that glosses its allusions as well as the meaning of its activity.

Maximus is a big poem, the "sort . . of epic" Olson mentioned in "Projective Verse"-a demonstration, in fact, of his belief that the practice of projective verse might solve the "problem of larger content and of larger forms. . . The numbers indicate the limits of the present volume and promise subsequent poems, and the initial poem addresses us (intimately: Whitman's you whoever you are) at a pitch of high resolve, with unusual verbal force, and with a didactic, moral insistence as reminiscent of Pound, perhaps his most conspicuous teacher, as of Maximus of Tyre, a mediator or model of the self Maximus of Gloucester sometimes assumes and Olson assumed when he introduced himself with this poem in Origin 1, the issue featuring him. "Charley," Fielding Dawson says in The Black Mountain Book, "was possessed by his voice," and he counsels later in this valuable emotional memoir of Olson during the years these poems were written, "If you want to understand Charley's poems, he's talking." Like Apollonius of Tyana, whose life fables Olson even more than that of Maximus of Tyre, he "talked to live. . .." He was a man of voices-sometimes disconcertingly theatrical, as in the NET film in which he reads "The Librarian." But the voice of "I, Maximus of Gloucester, to You," is modulated, not always pitched to passion, personal, always, in its public task, leaving the impression, appropriate to what in epic poems would be the invocation, of largeness. That the task he set himself was large is evident in the evocation not only of Pound but of Williams, Eliot, and Hart Crane, poets whose long poems challenged his own maximum effort. And it is evident too in the epigraph, which Olson, characteristically, employs as a text to be unfolded by meditative enactment. This text is an obstructive element, at least to those who must fully gloss it before entering the poem. What is most immediately available is Maximus' position in respect to Gloucester and to us (assuming, as I think the reader does, that the "you" he addresses is the reader, that he too belongs to those "islands / of men and girls" whom the equally isolated Maximus, concerned with creating a polis, elects to address in "Letter 3"; the poems, after all, are letters, communications; Williams is right to note the poet's loneliness). Maximus is "off-shore," which permits him, as in "The Librarian," to observe Gloucester in overview and as Olson's private landscape; and his off-shore position evokes a discoverer (public task) and a voyager returning home (private need) as well as the fisherman, summoned by "lance," the striking-iron, who are the heroes of Gloucester he 
most often celebrates. The difficult phrases are "hidden in the blood" and "a metal hot from boiling water," the first suggesting the equation of sea and blood, outer and inner waters, self and world, double, inseparable dimensions of the poem, and the second, calling up, with the help of "lance," the urgency, even aggressive force, of his purpose-in this he is like Ahab, though his purpose otherwise-a purpose not altered by but complexly elaborated by Olson's own remarks:

Maximus, Hero, a metal hot from boiling water, born in the winter, 1949-50, age 38-39. Sprang easily into anything, including busses; and in the spring, year 1952, succeeded easily in walking through New York City in one day, to the tune of $\$ 2,500$. A day.

Not himself a partisan of conventional heroes, Olson may be excused the tall-tale exuberance with which he responds to the emergence of the central figure of the poems. It is a great moment, like the watershed he notes in Apollonius' life: "He is now 40 years old, and at last aware of the dimension of his job. ..." It is the moment, as the allusion to Whitman's emergence reminds us (Emerson had brought the simmering Whitman to a boil), of confirmation and resolution, the outsetting bard hoping to cease only with death. What follows this is not of immediate referential importance but provides a clue to the Oedipal motive of the work:

O.K. That took care of Ma. The Hero though has also to be the King's son. This is very difficult in a democratic society. In a democratic society all men are fathers, like all women are mothers. This is not the same as being the King. By no means. The old man has to die, you have to succeed and not that one, here, of success: it has to be rule. You are omnipotent. Thus you do be what you were which you were born for....

Olson acknowledges, in an autobiographical statement, that, at 40 , he was still "hugely engaged with my parents," that their presence in him constituted part of the "live past" he explored.

The key words in Maximus' message to us are "lance," "obey," "dance." They involve a crucial matter of the poem, the crucial matter of Olson's desire to "restate man . . . repossess him of his dynamic," the matter of stance first treated in "Projective Verse"-how to stand a thing among things in a world in process, how, in Olson's reminiscently Thoreauvian words, to front reality-and they apply to, are exemplified by, both fishermen ("how shall you strike, / o swordsman, the blue-red back") and poet (for the lance is also a pen and the figures of the dance are syllables). Both fisherman and poet are men of skill, of attention and care ("eyes"), and are as- 
similated to each other throughout the poems, explicitly in "Letter 6." Their stance is creative, for it is the readiness, the responsiveness to the field in which one finds oneself, the quick attentiveness to change, to the moment, the possibility that summons one and defines "that which you can do!" It is creative, according to Olson, because in this participant action one is himself the "mover of the instant. ..." Moreover, stance may be accompanied by love because, as Olson taught Fielding Dawson, love is a verb, an action; "love is form," is what is done in the world, is "to make things," as he says of William Stevens, the colonial carpenter, the "first Maximus"-to make necessary things, nests, houses, poems.

The initial verses situate the poet in the field of his endeavor and call him to his task. They also introduce us to Gloucester, place us in space, in a "culture of immediate references" (Williams' phrase in "The American Background"). We are in the harbor-section, the old, preferred, still virtuous part of the poet's city, itself bowl-like, a nest, dominated in this poem, as in no other, by the gulls, tutelary birds, immemorial presences of place, exemplary, too, nest-builders, form-creators, weaving from miscellaneous materials, as the poet himself is doing and will do, and, what is more, of all creatures, for Olson, most wonderfully equilibrated in the field, paragons of stance. (We remember Olson's excitement over the chii-mi at the beginning of Mayan Letters and his admiration, in "A Round \& A Canon," for a bird in "his own world, his own careful context, those / balances.") And these verses initiate themes-they are insistences of the field, issuing from it, not imposed on it-and in them the poet begins to chart the moral geography of place.

The most important theme, subsuming stance and love, is self-action"those self-acts," "the tasks / I obey to" treated in "Letter 9." It is treated here most explicitly in section 4 , which resumes and modifies "love is form" in section 2:

one loves only form, and form only comes into existence when the thing is born

born of yourself, born

of hay and cotton struts, of street-pickings, wharves, weeds you carry in, my bird

of a bone of a fish of a straw, or will of a color, of a bell of yourself, torn 
Olson especially liked these quatrains so admirably woven of the previous materials of the poem and brought to coherence by vowel-modulation, consonance, anaphora, internal rhyme, and rhythmic movement. Their theme is particularly his own, connected, as we will see, with tropos, with the self's answering growth to the petitioning energies of the world. What concerns him here is that created things are born of the self, of its own psychic travail and the materials it brings in in its forays on its immediate environment, and, as the placing of the quatrains indicates, that the act of creation is assertive, resistant. A resistant stance is one of the notable things about Olson: his verse is not only percussive (as in section 6) and prospective (open to what lies "around the bend"), but projectile. In Maximus IV he gives us his acute sense of environmental pressure and the necessity he feels he is under to push against it:

... forever the geography
which leans in
on me I compell
backwards I compell Gloucester
to yield, to
change

And since "Polis / is this," he is at the very start about this work, about the difficult task of making a poem-creating the polis, refounding Gloucester in its verbal space-when its very materials are not, as he says, easy to love. His revulsion at Gloucester, at the city beyond the harbor-its streets are immediately explored in "Letter 2" and the moral geography of sea and land, perhaps derived from Melville, made explicit-is similar to the revulsion at contemporary culture of Williams and Pound. And they are very much present to him, as the echo in "but how shall you know" of "But how will you find" from the preface to Paterson, where a similar issue is confronted, and the borrowing of "pejorocracy" from Pound, tell us. Pound is the dominant presence in this poem, not only in the "rhythmic assemblies" Williams complained of, but in the "violent prejudices" he also noted, prejudices that, as in the present instance of harbor vs. city, take the form of either-or, melodramatic, perhaps even conspiratorial oppositions. "Pejorocracy" and "mu-sick," conspicuous thematically, are certainly unlovely, as are the worse rule and false language and the sick music and muzak they name. But is the case so extreme, or only the poet's revulsion, a revulsion that finds expression in Lear's outraged "o kill kill kill kill kill," an expression, too, of one of the poem's major themes: 


\title{
o kill kill kill kill kill \\ those \\ who advertise you \\ out
}

Out-in, another opposition. Against those who betray his "sea-city," who neither look to sea nor reverence "my lady of good voyage," the guardian, the tutelary deity, of the fishing community, and who do not know, as he says in "Letter 2," that

\author{
it is elements men stand in the midst of, \\ not these names supported by that false future she, \\ precisely she, \\ has her foot upon
}

-against these he enjoins the "in! in!" of creative action, the raising of the mast that establishes the center of the new-found polis. The argument may be said to be phallic, like Whitman's, and Williams' too, who links going-in with discovery. ${ }^{1}$ It has unusual physical force.

"I, Maximus of Gloucester, to You" opens the world and themes of what follows. In this, it reminds one of "Proem: to Brooklyn Bridge." And like Crane's poem, for all that is dismaying in what it surveys, it is optative, a summons to creative work. Placed as he is, Maximus is not subdued by musick. He "can still hear." He has the power of listening Olson treated in "Projective Verse," and he knows how to play (it) by ear, both attend the syllables and play things in the field as they come. For him the commonplace is wonderful, and "life as spirit," as Olson says in "Apollonius of Tyana," "is in the thing, in the instant, in this man." The universe is open, we are equal to its occasions, and meeting the instant may, in Williams' words in Paterson, "begin to begin again."

The Maximus Poems $1-10$ is a much better book than Williams thought it to be. It is coherent, having the intrinsic order-tension demanded by field composition. The poems vary in immediate difficulty but, as with Paterson, may be quickly read through with pleasure. Since composition is by field, the poems have the shapes of the poet's activity of thought; their forms are the extension of their contents. Yet in the way the themes are woven together the poems appear to follow a track, and Olson's practice of gathering various themes together in concluding sections (at the end of "Letter 1," for example) seems artful rather than spontaneous. The art of projective verse, however, is in minding spontaneity, and one finds this skill in Olson's letters where he follows the thread of thought over pages of seemingly di- 
gressive movement. Certainly in an enterprise involving him as intensely and continuously as these Maximus poems he would have been equal to the need for coherence.

There is no narrative line in these poems. They do not advance, have no particular forward direction. Instead they get the large work under way, begin to move in place, to take possession of place. Olson follows his advice to Ed Dorn to dig (in) one place, though he has not yet consulted in the poems any documents, and the colonial and pre-colonial history of America, prominent in the later poems, becomes foreground only in "Letter 10." These poems involve the present time, Gloucester now, and the poet's need to move, to work in, and to establish the terms that chart the field and enable him to tell "the Fables and the Wills of man...."

The terms, of course, have thematic importance and, as we have seen, are binary, composed of opposing elements, each pair clustering with others to develop the range of the poet's values. Of primary importance is the geographical pair, sea vs. land; to which one adds the directions, outward vs. inward; the occupations, fishing (and poetry) vs. capitalism (slaving, advertising, etc.); the polities, polis vs. pejorocracy; the economies, local vs. absentee; the stances, the "old measure of care" (of eyes, of ears) vs. carelessness (abstraction); the applications, work vs. sloth; and the goals, eudamia vs. euphoria. These values, moreover, are told by the senses: by sight ( the white vs. black, for example, of "Letter 2"), by smell (tansy vs. gurry and the slime of ownership), by hearing (bells vs. musick), by touch (contact vs. withholding). In charting the field, they dramatize what Olson called "the binary problem"-"that at any moment of essential experience you are making a choice...."

The most prominent concern of these poems-it is prominent also in subsequent installments-is "the practice of the self." As in the earliest poems in Archaeologist of Morning and in the writing that culminates in The Special View of History, Olson is preoccupied with a question of both public and personal urgency: how to act? He is preoccupied with the "actual willful man" who must do "something about [with?] himself," who, perforce, asks, "what act? what shall we do with Papa's shovel? what shall we do? ..." In "The Songs of Maximus" ("Letter 3") he writes:

And I am asked-ask myself ( $I$, too, covered with the gurry of it) where shall we go from here, what can we do

The question specifically relates to art as an action and finds an answer in "Letter 5," the longest, most reproving and scornful poem of this installment. In this letter, Olson addresses Vincent Ferrini, a poet and the editor 
of Four Winds (where Olson published three of the Maximus poems!), a man, he feels, who has misconceived his task, has bungled it as badly as the skipper who in a storm abandoned two men at sea. A little magazine, like Origin, whose policy Olson did much to shape, might be a polis, a "place we can meet," but Ferrini has betrayed that possibility by seeking guidance everywhere except in the "context of / now," in the elements of the local place, the very Gloucester Olson knows intimately; with recollections of it he salts his disapproval and claims his nativity. In terms of the issue of language set forth in pejorocracy and musick (song, or poetry, is an alternative), Ferrini's act is equivalent to that of the absentee owners who advertise us out. He has failed at "men's business," that which confronts the elements and requires the "old measure of care." Not only has he failed to see out of his own eyes, which is a privilege Olson restores in "Letter 6" ("There are no hierarchies, no infinite, no such many as mass, there are only / eyes in all heads, / to be looked out of"), he has not had "the polis / in [his] eye...."

Olson himself is as much the proper model in respect to Ferrini as are the fishermen he holds up as exemplary. But in respect to Marsden Hartley, another artist treated in these poems, the exemplary figure is his father. The issue in this letter (7), which continues the treatment of eyes, attention, and care in terms of "hands" ("hands are put to the eyes' commands"), is unmediated contact with things. Hartley, a painter connected with Gloucester only because in the 1930's he painted her landscape and chiefly that of Dogtown, the uninhabited moraine north of the town, is not contemned. ${ }^{2}$ Olson acknowledges his "many courages." What he disapproves of is his "transubstantiations," the way in which he transformed all things to cloth, made the Whale's Jaw, the particular instance related to his father, a "canvas glove." This is as much as to say that Hartley engaged reality with his gloves on, that he did not follow the way of objectism, proposed by Olson in "Projective Verse," but rather that of the egotistical sublime:

\title{
Such transubstantiations
}

\author{
as I am not permitted, \\ nor my father, \\ who'd never have turned the Whale Jaw back \\ to such humanness neither he nor I, as workers, \\ are infatuated with
}

This passage is of interest also because Olson identifies with his father and defines the artist-the carpenter prefigures this-as a worker. His father, he says, took the Whale's Jaw "as he took nature, took himself. . .." He was a 
man of attention and care, dealing directly with things, and Olson, in the excellent short story "Stocking Cap," depicts him with an admiration that measures his own incapacity. ${ }^{3}$ Here, he is Jehovah!

\author{
Jehovah, he looks that strong \\ he could have split the rock \\ as it is split, and not \\ as Marsden Hartley painted it \\ so it's a canvas glove
}

But why did Hartley do this? Why transubstantiate? Because he refused "woman's flesh." The remark-the disclosure, in the concluding line, shocks us-is unkind but may be justified because its truth had already been revealed in Paul Rosenfeld's study of Hartley in Port of New York and Williams' account of Hartley's homosexuality in the Autobiography.

Of course the most conspicuous example of behavior is Olson himself, for The Maximus Poems provide him the satisfaction he speaks of in The Special View of History: creating the history of one's self. The entire poem is his act, and much in these early poems involves his stance and preparatory enabling acts. We learn, for example, that he has adopted voluntary poverty. "The Songs of Maximus" ("Letter 4"), in which he tells of the "blessings" of the leaky faucet and the faulty toilet-this particular song recalls Williams' "Le Médicin Malgré Lui"-are themselves repudiations of the wanting encouraged by advertising. He sings because he "wants" something else, because "wondership," as exemplified in the account of recognizing Nike, moves him more than "ownership." There is bravado here as there is in "The Green Man," an early poem originally entitled "In Praise of the Fool," in which he advises the fool to turn from the way of politics ("chase a King") to the way of poetry ("furiously sing!"). Prompted by outrage at contemporary culture, these songs are his furious singing. We learn too in "Letter 6" what he confesses later in "Letter 12": that the sea was not his trade, that he lacks the skills of professionals, wastes his eyes. He admits that "I have suffered since, / from that enthusiasm," but it's as much competitiveness as enthusiasm, as the subsequent anecdote of mountain-climbing tells us. He acknowledges the folly, but is proud of the fact that his sharpness comes of "pushing . . . limits." In the context of "Letter 5"-“Limits / are what any of us / are inside of"-the implied injunction is to move outward beyond them. The Olson of these poems is an adventurer; he risks himself.

There is nothing conspicuous in this, and the letters that address it, reaching deeply to the speculative sources of Olson's work, are the meditative center of these poems. In "Tyrian Businesses" ("Letter 8"), the poem under 
hand is his "exercise for this morning," an example of "how to dance / sitting down"; in "Letter 9," which develops the idea of tropos in the previous letter, the concern is "self-acts" and "self-things," intrinsic growth and the making of poems. Olson tells us in "A Syllabary for a Dancer," the essential gloss on "Tyrian Businesses," that man is "a thing which simultaneously thinks and dances," that he is concerned with using himself, with self-originating action, with "the kinetic as the act of life," the movement that engages things and makes them yield "that life which matter is so astoundingly capable of anew each day in each new human hand." For Olson, himself a dancer, movement is the basis of renewal: only get under way, begin the work by which one attacks chaos. But it must be movement of the kind exemplified here, vertical movement, having its origins, its tropos, in the chaos within oneself, in what is "implicit in himself, inside himself, what he is and what he is impelled to do, that is, how to move." The distinction between vertical and horizontal movement is crucial, and of historical import. For Olson connects the horizontal with the American westward movement, with "frontierism" and dispersion. American history follows the pattern of post-Sumerian history traced in "The Gate and the Center": dispersion, loss of center, of coherence. Horizontal movement, accordingly, no longer serves "the last first people," Olson's characterization of the Americans in Call Me Ishmael ("We are the last 'first' people. We forget that. We act big, misuse our land, ourselves"). The business of "Tyrian Businesses" is indeed Tyrian, that of a Maximus concerned with, prescribing for, his country, "my countree," he says in "Letter 10," the true, still to be discovered, America. And in these poems, as in the "Syllabary," he is still hopeful for America. With dispersion behind them, the Americans, he says, are "green again"; at last they have discovered "physicality" (that they are things among things) and "know what the earth is. ..." Now they need only learn to sit.

Section one of "Tyrian Businesses" transposes the "Syllabary," and section two continues the poet's morning work, much of it his seemingly casual consulting of the dictionary. It is proper morning work, answering to Olson's stirring affirmation of himself as an "archaeologist of morning": "This is the morning after the dispersion, and the work of the morning is methodology: how to use oneself, and on what. That is my profession, I am an archaeologist of morning." Heart, metacenter, tropaeolum, eudaemonia-the definitions of these words, among others, provide the substance of a meditation on tropos, the inward-arising motion, the twisting and turning common to organic growth and verse. Tropos is self-action and its linguistic complement is the middle voice, mentioned here and in the "Syllabary" and defined later in Proprioception as the voice of "proprious-ception / 'one's own' -ception." In the middle voice, Olson explains, the subject is represented as acting on himself, for himself, and on something belonging to oneself-actions, inci- 
dentally, that yield him articles of faith: will, believe, be graceful, obey, accept self-responsibility.

Here, too, beginning proprioceptively with the contractions of the heart, he ponders the courage needed to live in a process world, a world of change. He considers his flower, the nasturtium, "my nose twist, my beloved, my / trophy"-a flower of the genus Tropaeolum, a kind of cress, pungent like tansy, associated by him with the "Tansy from Cressy's / I rolled in as a boy" ("Letter 3"). Flowers and flowering, as the subsequent poem bears out, are primary images of tropos, as important to him as they are to Williams; when he speaks in the "Syllabary" of vertical kinetics his example is "growing, and waving from the spine, like flowers are, or branches, on a tree." And since knowing how to dance sitting still is a "gravity question," he is properly concerned with the relations of $M$ to $G$, of metacenter to gravity. A buoy or ship, after all, must be self-righting in any weather; must, as he shows in defining "felicity," move in accord with reason or nature. Futtocks and fylfot complete the logic of these definitions: felicity is a strong, lucky ship, able to survive storm and accident, or, in human terms, the lucky reward of those who are courageous, know how to grow, and move gracefully.

Or, as he declares in "Letter 9," the splendid poem of spring following on this poem of morning, felicity comes of obeying what Emerson called the soul's emphasis, the tropic insistences of the self. The analogue of the self is the flower; the "likeness," he says, "is to nature's"; and "there are these necessities [natural process itself] / are bigger than we are." The poem celebrates a double flowering, that of "the flowering plum" and of his book of poems, In Cold Hell, In Thicket, just published in Mallorca. And since the latter reminds him of the fate of an earlier book, Call Me Ishmael ("as, in another spring, / I learned / the world does not stop / for flowers"), it raises for him the always disturbing question of contemplation vs. action, of the way of art vs. the way of acceptable public usefulness. Though Olson turned from politics to art, he did not abandon public ends: he says here that he wished that his book of poems "might stop / the workings of my city." And that it doesn't disturbs him:

\author{
it puts a man back \\ to find out how much \\ he is busy, this way, \\ not as his fellows are \\ but as flowering trees ${ }^{4}$
}

It disturbs him, and makes him defensive. Yet the intrinsic success of flowering is, as it had been for Thoreau in "Wild Apples," his chief argu- 
ment, rehearsed here, one feels, to earn again and reaffirm his choice. Flowering, whether in the growth of the self or in the publication of books, is an end in itself ("these things / which don't carry their end any further than / their reality in / themselves"). And what interests him now, he says, is not extrinsic success but rather his own springlike condition, what he had referred to in the previous poem as "the seedling / of morning: to move, the problems (after the night's presences) the first hours of . ..":

\author{
It's the condition in men \\ (we know what spring is) \\ brings such self-things about \\ which interests me \\ as I loll today \\ where I used to \\ atop Bond's Hill
}

His posture recalls Whitman's in "Song of Myself" and his survey of Cape Ann recalls Thoreau, in Walden, the monarch of all he surveys-the only monarch Olson chooses to be. And one element of the condition in men that accounts for such self-things as this poem is resistance, the versus the poem insists on as Olson opposes himself ("myself") to King Alfred, to history ("tempestuous / events"), to the tasks of the nation ("men's affairs"). To borrow the opposing Keatsian terms of The Special View of History, he would be a man of achievement, not a man of power, and he would obey the imperatives of his own being:

\title{
versus
}

my own wrists and all my joints, versus speech's connectives, versus the tasks I obey to

He obeys his own turnings and twistings, and verse, itself a turning, is his opposing force. $\mathrm{He}$ is assertive; at the close of the poem the self is the measure of itself, and like the bee, whose buzzing also occurs elsewhere in the poem, he is angry at failure yet moved by it to poetic action.

The task for which all of this prepares is stated, finally, in "Letter 10," which both concludes this installment and opens into the subsequent poems:

on founding: was it puritanism, or was it fish?

And how, now, to found, with the sacred \& the profane-both of themwore out 
The beak's

there. And the pectoral.

The fins,

for forwarding. [These images resume "Letter 1"]

But to do it anew, now that even fishing ...

Past and present juxtapose. Founding and refounding. The past begets the present, and the way its possibilities were dispossessed is repeated, the destructive agents, like Endecott (later associated with J. B. Conant of Harvard), destroying the beneficent founders, like Roger Conant, whose Tudor house, the first house built in Gloucester, "sat [at Stage Fort] / where [Olson says] my own house has been (where I am / founded." The history to which this poem may be taken to be prologue is of battle and destruction, of fierce oppositions, and it is still alive for Olson because historical dispossession is also a personal dispossession. Olson's concern with originswith the founding-is prompted by the present need to refound. "The green republic now renewed": this entry in early notes on "Man is Prospective" states his public theme. The correlative private theme involves what is often a reverie toward childhood-an imaginative repossession of place, as the true place, the "my countree" of being and well-being with which he closes.

The concluding sections of this essay-in and about The Maximus Poems 11-37-will appear in The Iowa Review for Summer, 1975 (6/3).

\section{NOTES}

1 Later, this distressed Olson. See Charles Olson, Reading at Berkeley (San Francisco: Coyote, 1966), p. 34.

2 Olson treats Dogtown in Maximus Poems IV, V, VI. For Hartley's paintings, see Portrait of a Place: Some American Landscape Painters in Gloucester, and for historical and topographical information, see Joseph E. Garland, The Gloucester Guide: A Retrospective Ramble. Both books are publications of the Gloucester 350th Anniversary Celebration, Gloucester, Massachusetts, 1973.

3 Olson's directness is "political" and is related to his father's leadership of the postal workers' union, referred to in "until all bosses struck him down." Olson's father also pushed his limits and died, as Olson himself feared he would, of a heart attack.

4 The problem was an enduring one, attested to by Olson's Reading at Berkeley, where, in a decade wholly different from the 1950's, he took pleasure in saying that "poetics is politics, poets are political leaders today ..." (p. 15). Olson read this poem at Berkeley. 